Article

\title{
Antineoplastic Activity of Chrysin against Human Hepatocellular Carcinoma: New Insight on GPC3/SULF2 Axis and lncRNA-AF085935 Expression
}

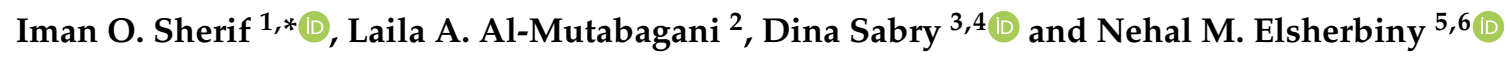 \\ 1 Emergency Hospital, Faculty of Medicine, Mansoura University, Mansoura 35516, Egypt \\ 2 Chemistry Department, College of Science, Princess Nourah Bint Abdulrahman University, \\ Riyadh 11671, Saudi Arabia; laalmutbagani@pnu.edu.sa \\ 3 Medical Biochemistry and Molecular Biology Department, Faculty of Medicine, Cairo University, \\ Cairo 11562, Egypt; dinasabry@kasralainy.edu.eg \\ 4 Medical Biochemistry and Molecular Biology Department, Faculty of Medicine, Badr University in Cairo, \\ Badr City 11829, Egypt \\ 5 Biochemistry Department, Faculty of Pharmacy, Mansoura University, Mansoura 35516, Egypt; \\ drnehal@hotmail.com \\ 6 Pharmaceutical Chemistry Department, Faculty of Pharmacy, University of Tabuk, \\ Tabuk 71491, Saudi Arabia \\ * Correspondence: emyosh@yahoo.com or iosherif@mans.edu.eg
}

Received: 22 August 2020; Accepted: 13 October 2020; Published: 15 October 2020

\begin{abstract}
The natural flavonoid chrysin possesses antiproliferative activity against various types of cancers, including hepatocellular carcinoma (HCC), which is a common malignancy. However, the exact mechanism of chrysin antiproliferative activity remains unclear. This research was executed to explore the impact of chrysin on glypican-3 (GPC3)/sulfatase-2 (SULF2) axis and lncRNA-AF085935 expression in HCC using HepG2 cells. Cisplatin $(20,50,100 \mu \mathrm{g} / \mathrm{mL})$, chrysin $(15,30$, and $60 \mu \mathrm{g} / \mathrm{mL})$ and the combination of $50 \mu \mathrm{g} / \mathrm{mL}$ cisplatin with different concentrations of chrysin were applied for 24/48 h. Cell viability was determined by MTT assay. Protein levels of GPC3 and SULF2 were measured by ELISA at 24/48 h. GPC3 immunoreactivity was detected by immunocytochemistry. Moreover, GPC3 and SULF2 mRNA expressions in addition to lncRNA-AF085935 expression were assessed by qPCR at $48 \mathrm{~h}$. The GPC3 protein, immunostaining and mRNA levels, SULF2 protein and mRNA levels, as well as lncRNA-AF085935 expression, were decreased significantly with cisplatin and chrysin alone when compared with the control untreated HepG2 cells. However, the combination treatment exhibited a better chemopreventive effect in a dose- and time-dependent manner. This study demonstrated, for the first time, the antiproliferative activity of chrysin against HCC through the suppression of the GPC3/SULF2 axis along with the downregulation of lncRNA-AF085935 expression. Synergistic effect of chrysin with cisplatin could potentiate their antiproliferative action in a doseand time-dependent manner.
\end{abstract}

Keywords: hepatocellular carcinoma; Chrysin; GPC3; SULF2; lncRNA-AF085935

\section{Introduction}

Liver cancer is a serious health problem and is considered the world's main cause of cancer related death. The most prevalent type is known as hepatocellular carcinoma (HCC) [1]. Retarding the progression of HCC is the target plan for physicians to improve a patient's prognosis [2]. Although physicians have tried their best to treat HCC through surgical operations, either by liver resection or liver transplantation, missing early diagnosis led to poor prognosis [1,3]. Unfortunately, most HCC 
patients are diagnosed at their advanced stages with systemic chemotherapies being the only treatment option [4].

Currently, the chemotherapeutic agents utilized for HCC are associated with deleterious adverse effects on their use [5]. Therefore, the use of natural products, either alone or in combination with conventional chemotherapy, is gaining great interest. Indeed, various studies applied natural products as sole treatment or combination regimens with common chemotherapy for the purpose of HCC treatment and/or reduction of the cytotoxicity of chemotherapy [6-8]. Cisplatin is one of the most effective and frequently used chemotherapeutic drugs for the management of HCC, with high response rates and favorable long-term outcomes [9]. Currently, multiple studies are focusing on developing novel combination regimens to potentiate cisplatin antiproliferative efficacy and facilitate its clinical application $[10,11]$.

The natural polyphenolic compounds that occur in plants were known as flavonoids and possess various beneficial pharmacological actions including anti-inflammatory, antiapoptotic, antioxidants, and anticancer activities [12,13]. One of these natural flavonoids is chrysin, with the chemical structure of 5,7-dihydroxyflavone, which is present in propolis and honey [14]. The chrysin antitumor activity was documented in various types of human cancer cell lines, including gastric [15], breast [16], colorectal [17], and prostate [18] cancer cells due to its ability to induce cell apoptosis and cell cycle arrest [19]. Interestingly, previous studies showed the antitumor potential of chrysin against HCC through p53/Bcl-2/caspase-9 pathway activation [20] and targeting hexokinase-2 [12]. Notably, chrysin has been reported to alleviate cisplatin-induced liver [21] and colon [22] toxicity, highlighting its beneficial use as combinational therapy with cisplatin. However, the exact mechanism of chrysin anti-proliferative effect remains unidentified.

On the other hand, remodeling of the extracellular matrix (ECM) is significantly involved in the control of HCC differentiation, proliferation, and metastasis [23]. Heparan sulfate proteoglycans (HSPGs) are ECM cell surface macromolecules comprised of a core protein attached to chains of heparan sulfate glycosaminoglycan (HS GAG). Glypicans (GPCs) are cell surface HSPGs and are connected to the plasma membrane by glycosylphosphatidylinositol (GPI) link [24]. Glypican-3 (GPC3) acts as a storage site for some ligands through the HS side chain. GPC3 enables ligand/receptor interaction to stimulate various signaling pathways incorporated in the progression of the HCC [3].

The extracellular enzyme sulfatase 2 (SULF2) is involved in the tumorigenesis and progression of several carcinomas through alteration of sulfation on HSPGs. SULF2 is characterized as having a 6-O-desulftase activity, which removes the 6-O-sulfate from HSPGs, minimizing the affinity of HSPGs to sequester signaling ligands, leading to their release from the HSPGs storage sites and driving them accessible for activating various pathways $[25,26]$.

Additionally, it was reported that GPC3 and SULF2 overexpression were associated with HCC growth $[3,27,28]$. GPC3 is currently considered as a trustable indicator for the HCC earlier diagnosis and prognosis than serum alpha-fetoprotein $[3,27]$. Moreover, SULF2 was reported to be a crucial indicator for the prognosis of HCC [28]. Beside their diagnostic value, a large body of evidence reported that targeting GPC3 and SULF2 is a promising therapeutic approach for HCC [29,30].

Likewise, long noncoding RNA (lncRNA), with $>200$ nucleotides length, have been recently emerged as gene expression regulators in cancer cells, including HCC [31]. Several lncRNAs are dysregulated in liver cancer cells and have been linked to crucial signaling pathways of tumorigenesis. These dysregulated lncRNAs are strongly suggested as novel diagnostic biomarkers and/or therapeutic targets for HCC [32]. Specifically, the IncRNA-AF085935 was highly expressed in HCC and could be used as a vital biomarker for HCC [33]. This study was carried out to discover a new insight of the antiproliferative action of chrysin alone or with its concurrent treatment with cisplatin against HCC through the impact on the GPC3/SULF2 axis in addition to lncRNA-AF085935 expression. 


\section{Results}

\subsection{Chrysin Combined with Cisplatin Decreased Cell Survival in HepG2 Cells}

The MTT assay was utilized to evaluate the impact of chrysin and cisplatin (alone or in combination) on HepG2 cells proliferation (Figure 1). Cisplatin (20, 50, $100 \mu \mathrm{g} / \mathrm{mL})$ (A) and chrysin (15, 30, $60 \mu \mathrm{g} / \mathrm{mL}$ ) (B) sole treatment for 24 and $48 \mathrm{~h}$ markedly reduced the survival of HepG2 cells in a concentration-dependent manner when compared with the control untreated HepG2 cells, $(p<0.05)$. The combination of chrysin $(15-60 \mu \mathrm{g} / \mathrm{mL})$ with cisplatin $50 \mu \mathrm{g} / \mathrm{mL}$ treatment for 24 and $48 \mathrm{~h}$ significantly reduced the HepG2 cells survival when compared with chrysin $(15-60 \mu \mathrm{g} / \mathrm{mL})$ alone or cisplatin $50 \mu \mathrm{g} / \mathrm{mL}$ for 24 and $48 \mathrm{~h}$, respectively ( $p<0.05$, Figure 1B). Moreover, our results documented that the significant reduction in cell survival was obtained in a time-dependent way in which more reduction in cell survival was determined after $48 \mathrm{~h}$ treatment compared to $24 \mathrm{~h}$ treatment $(p<0.05$, Figure 1$)$.

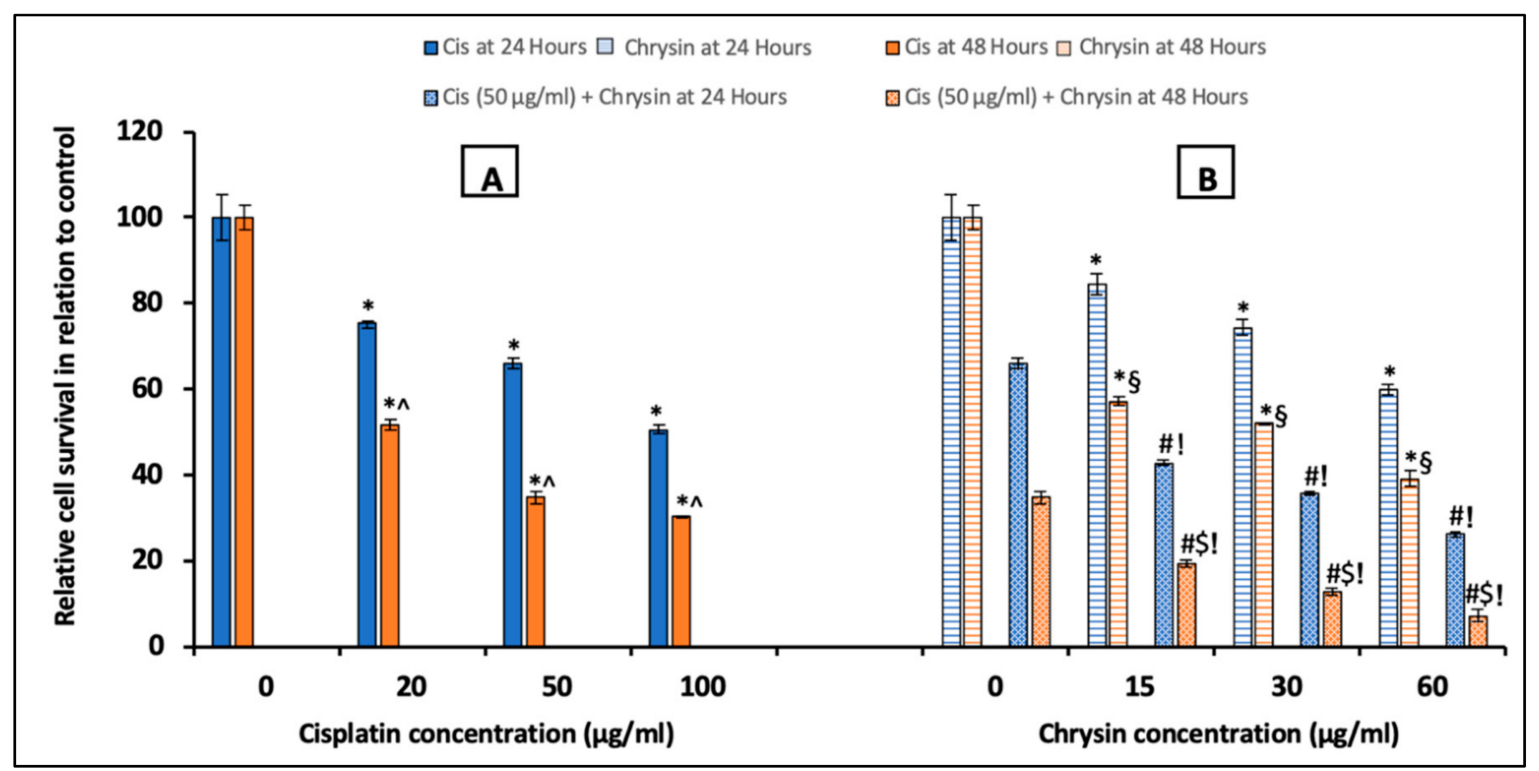

Figure 1. Impact of 24 and $48 \mathrm{~h}$ treatment with (A) cisplatin (Cis; 20, 50, $100 \mu \mathrm{g} / \mathrm{mL})$, (B) chrysin (15, $30,60 \mu \mathrm{g} / \mathrm{mL})$ and combination of chrysin $(15,30,60 \mu \mathrm{g} / \mathrm{mL})$ with Cis $50 \mu \mathrm{g} / \mathrm{mL}$ on cell survival in HepG2 cells. Results are presented as Mean \pm SD. ${ }^{*} p<0.05$ versus the control untreated cells. ${ }^{\wedge} p<0.05$ versus the same dose of Cis treatment for $24 \mathrm{~h} .{ }^{\#} p<0.05$ versus the same dose of chrysin at the same incubation time. ${ }^{!} p<0.05$ versus $C$ is $50 \mu \mathrm{g} / \mathrm{mL}$ at the same incubation time. ${ }^{\S} p<0.05$ versus the same dose of chrysin treatment for $24 \mathrm{~h}^{\$} p<0.05$ versus cis $50 \mu \mathrm{g} / \mathrm{mL}+$ the same dose of chrysin treatment for $24 \mathrm{~h}$.

\subsection{Chrysin Combined with Cisplatin Decreased Glypican-3 (GPC3) Protein and mRNA Expressions in HepG2 Cells}

To further examine the molecular mechanism of the antiproliferative activity of chrysin on HepG2 cells, we assessed GPC3 protein levels by ELISA at 24/48 h and immunocytochemistry (ICC) at $48 \mathrm{~h}$, in addition to its mRNA expression by qPCR at $48 \mathrm{~h}$ in cells treated with different concentrations of chrysin and/or cisplatin. Treatment with either cisplatin $(20,50,100 \mu \mathrm{g} / \mathrm{mL})$ (Figure 2A), or chrysin $(15,30,60 \mu \mathrm{g} / \mathrm{mL})$ (Figure 2B), notably reduced GPC3 protein levels after 24 and $48 \mathrm{~h}$ incubation in a concentration-dependent manner when compared with the control untreated HepG2 cells, $(p<0.05)$. 


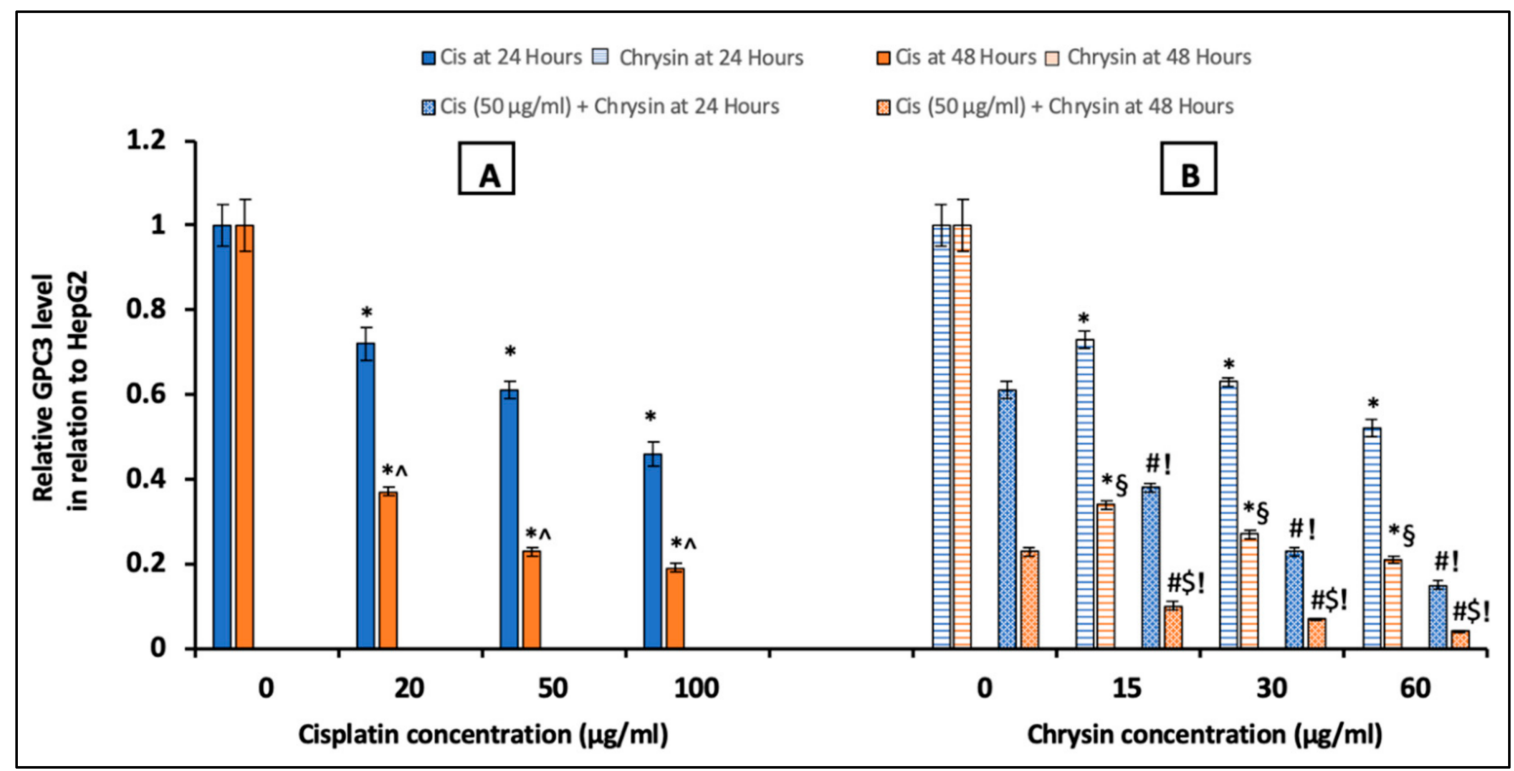

Figure 2. Impact of 24 and $48 \mathrm{~h}$ treatment with (A) cisplatin (Cis; 20, 50, $100 \mu \mathrm{g} / \mathrm{mL}$ ), (B) chrysin $(15,30,60 \mu \mathrm{g} / \mathrm{mL})$ and combination of chrysin $(15,30,60 \mu \mathrm{g} / \mathrm{mL})$ with Cis $50 \mu \mathrm{g} / \mathrm{mL}$ on glypican-3 (GPC3) protein levels in HepG2 cells. Results are presented as Mean \pm SD. ${ }^{*} p<0.05$ versus the control untreated cells. ' $p<0.05$ versus the same dose of Cis treatment for $24 \mathrm{~h} .{ }^{\#} p<0.05$ versus the same dose of chrysin at the same incubation time. ${ }^{!} p<0.05$ versus Cis $50 \mu \mathrm{g} / \mathrm{mL}$ at the same incubation time. $\S p<0.05$ versus the same dose of chrysin treatment for $24 \mathrm{~h} .{ }^{\$} p<0.05$ versus cis $50 \mu \mathrm{g} / \mathrm{mL}+$ the same dose of chrysin treatment for $24 \mathrm{~h}$.

The ICC for detection of GPC3 immunopositive cells at $48 \mathrm{~h}$, presented in (Figure 3A), showed higher GPC3 protein expression in control untreated HepG2 cells. Mild GPC3 protein expression with cisplatin treatment and moderate GPC 3 protein expression with chrysin sole treatment was observed in comparison to the control untreated cells. However, low GPC3 protein expression was observed in the combination-treated cells when compared to chrysin or cisplatin treated cells in a dose-dependent manner.

Regarding the statistical analysis of GPC3 immunopositive cells detected by ICC, our results documented that the used sole treatments significantly reduced GPC 3 immunostaining in HepG2 cells after $48 \mathrm{~h}$ incubation in a concentration-dependent manner when compared with control untreated HepG2 cells, $(p<0.05$, Figure 3B,C).

Additionally, GPC3 protein levels (Figure 2B) and immunostaining (Figure 3C) in HepG2 cells were markedly reduced on the combination of chrysin $(15-60 \mu \mathrm{g} / \mathrm{mL})$ with cisplatin $50 \mu \mathrm{g} / \mathrm{mL}$ treatment when compared with chrysin $(15-60 \mu \mathrm{g} / \mathrm{mL})$ single treatment or cisplatin $50 \mu \mathrm{g} / \mathrm{mL}$ for the same incubation time $(p<0.05)$. Furthermore, our data showed that the GPC3 protein level was statistically non-significant in case of treatment with chrysin $(15,30 \mu \mathrm{g} / \mathrm{mL})$ alone for $48 \mathrm{~h}$ when compared with chrysin $(15,30 \mu \mathrm{g} / \mathrm{mL})$ combined with cisplatin $50 \mu \mathrm{g} / \mathrm{mL}$ for $24 \mathrm{~h}$. However, more decline in the GPC3 protein expression was observed when using chrysin $(15-60 \mu \mathrm{g} / \mathrm{mL})$ combined with cisplatin $50 \mu \mathrm{g} / \mathrm{mL}$ for $48 \mathrm{~h}$ compared to $24 \mathrm{~h},(p<0.05$, Figure $2 \mathrm{~B})$.

On the mRNA level, HepG2 cells treated with cisplatin (20-100 $\mu \mathrm{g} / \mathrm{mL}$ ) (Figure 4A) or chrysin $(15-60 \mu \mathrm{g} / \mathrm{mL}$ ) (Figure $4 \mathrm{~B}$ ) for $48 \mathrm{~h}$ demonstrated a significant dose-dependent downregulation in GPC3 mRNA expression compared to the control untreated HepG2 cells. Moreover, co-treatment of chrysin $(15-60 \mu \mathrm{g} / \mathrm{mL})$ augmented the action of $50 \mu \mathrm{g} / \mathrm{mL}$ cisplatin on the downregulation of GPC3 mRNA expression in HepG2 cells when compared with Cis $50 \mu \mathrm{g} / \mathrm{mL}$ alone $(p<0.05$, Figure 4B). 

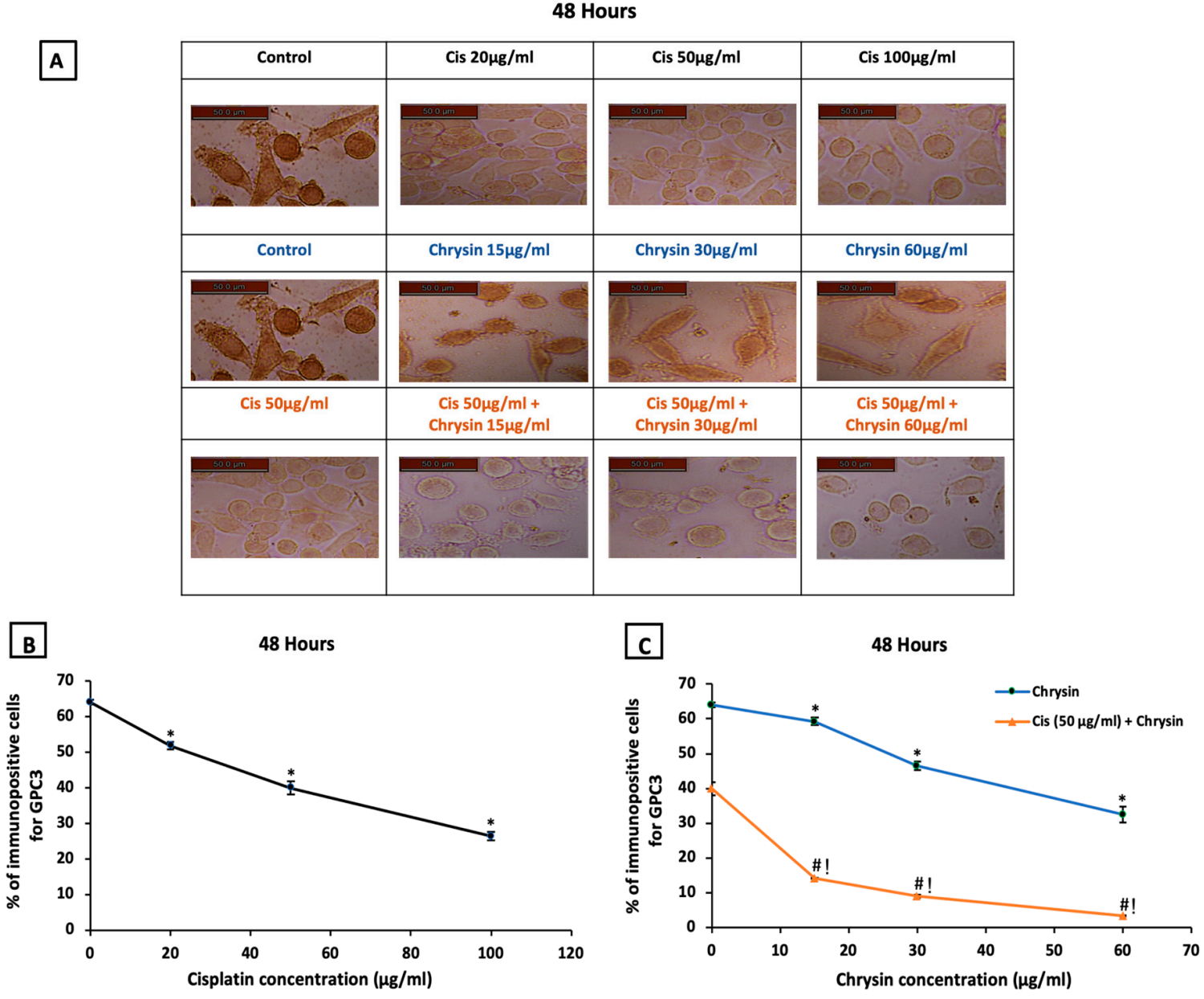

Figure 3. (A) Representative images of glypican-3 (GPC3) immuno-staining in HepG2 cells following treatments with cisplatin (Cis; 20, 50, $100 \mu \mathrm{g} / \mathrm{mL}$ ), chrysin $(15,30,60 \mu \mathrm{g} / \mathrm{mL}$ ) and combination of chrysin $(15,30,60 \mu \mathrm{g} / \mathrm{mL})$ with Cis $50 \mu \mathrm{g} / \mathrm{mL}$ for $48 \mathrm{~h}$, scale bar $=50 \mu \mathrm{m}$. Control untreated cells showed strong GPC3 immunopositive stain, Cis $(20,50,100 \mu \mathrm{g} / \mathrm{mL})$ treated cells showed mild GPC3 immunopositive stain, chrysin $(15,30,60 \mu \mathrm{g} / \mathrm{mL})$ treated cells showed GPC3 moderate immunopositive stain while, Cis $50 \mu \mathrm{g} / \mathrm{mL}+(15,30,60 \mu \mathrm{g} / \mathrm{mL})$ treated cells showed weak GPC3 immunopositive stain. (B) Statistical analysis of the \% of immunopositive cells for GPC3 after treatment with cisplatin (Cis; 20, $50,100 \mu \mathrm{g} / \mathrm{mL})$ for $48 \mathrm{~h},(\mathbf{C})$ chrysin $(15,30,60 \mu \mathrm{g} / \mathrm{mL})$ as well as chrysin $(15,30,60 \mu \mathrm{g} / \mathrm{mL})$ and Cis $50 \mu \mathrm{g} / \mathrm{mL}$ combination for $48 \mathrm{~h}$. ${ }^{*} p<0.05$ versus the control untreated cells. ${ }^{\#} p<0.05$ versus the same dose of chrysin. $! p<0.05$ versus Cis $50 \mu \mathrm{g} / \mathrm{mL}$. Figures for the control group in the upper and middle lanes and for the Cis $50 \mu \mathrm{g} / \mathrm{mL}$ group in the upper and last lanes are identical to unify the reference groups in the statistical analysis. 


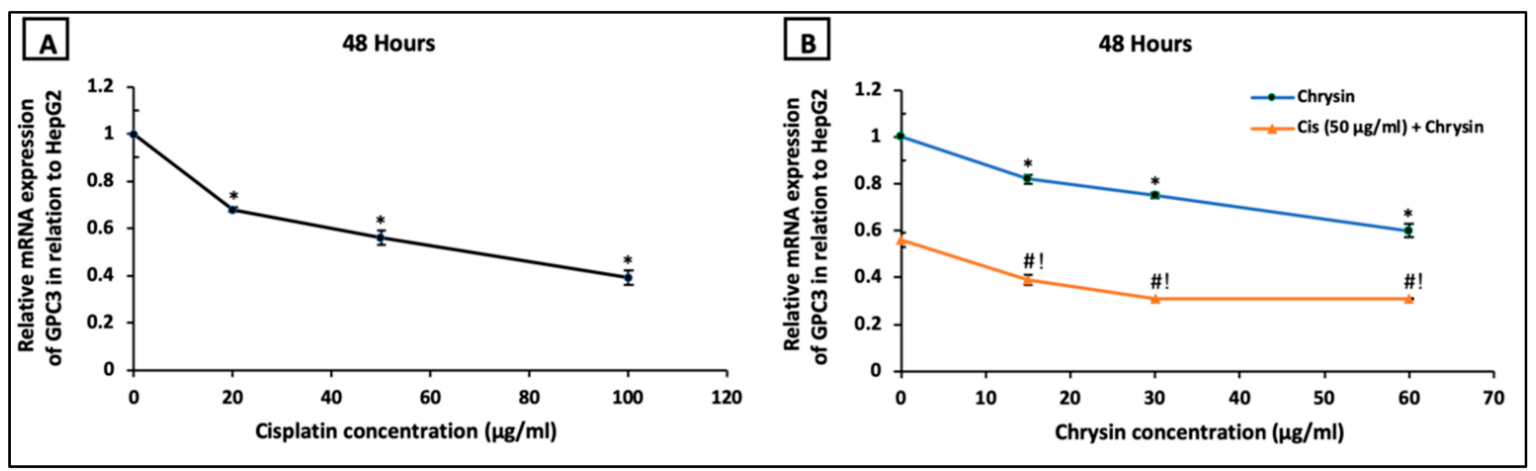

Figure 4. Impact of $48 \mathrm{~h}$ treatment with (A) cisplatin (Cis; 20, 50, $100 \mu \mathrm{g} / \mathrm{mL}),($ B) chrysin $(15,30$, $60 \mu \mathrm{g} / \mathrm{mL}$ ) and combination of chrysin $(15,30,60 \mu \mathrm{g} / \mathrm{mL}$ ) with Cis $50 \mu \mathrm{g} / \mathrm{mL}$ on glypican-3 (GPC3) mRNA expressions in HepG2 cells. Results are presented as Mean \pm SD. ${ }^{*} p<0.05$ versus the control untreated cells. ${ }^{\#} p<0.05$ versus the same dose of chrysin. ${ }^{\prime} p<0.05$ versus Cis $50 \mu \mathrm{g} / \mathrm{mL}$.

\subsection{Chrysin Combined with Cisplatin Decreased Sulfatase-2 (SULF2) Protein and mRNA Expressions in} HepG2 Cells

Regarding SULF2, ELISA analyses results were shown in Figure 5, in comparison to the control untreated HepG2 cells, incubation with cisplatin $(20,50,100 \mu \mathrm{g} / \mathrm{mL})(\mathrm{A})$ or chrysin $(15,30,60 \mu \mathrm{g} / \mathrm{mL})$ (B) alone for 24 and $48 \mathrm{~h}$ significantly reduced SULF2 protein levels in a dose-dependent manner. Moreover, chrysin $(15-60 \mu \mathrm{g} / \mathrm{mL})$ and cisplatin $50 \mu \mathrm{g} / \mathrm{mL}$ in combination for 24 and $48 \mathrm{~h}$ significantly decreased SULF2 protein levels in HepG2 cells when compared with chrysin $(15-60 \mu \mathrm{g} / \mathrm{mL})$ single treatment or cisplatin $50 \mu \mathrm{g} / \mathrm{mL}$ for 24 and $48 \mathrm{~h}$, respectively $(p<0.05)$. Moreover, in the current work, a non-significant difference of SULF2 protein level was observed in case of treatment with chrysin (15-60 $\mu \mathrm{g} / \mathrm{mL})$ alone for $48 \mathrm{~h}$ when compared with both chrysin $(15-60 \mu \mathrm{g} / \mathrm{mL})$ and cisplatin $50 \mu \mathrm{g} / \mathrm{mL}$ for $24 \mathrm{~h}$. However, better results were achieved when using the combination of chrysin $(15-60 \mu \mathrm{g} / \mathrm{mL})$ and cisplatin $50 \mu \mathrm{g} / \mathrm{mL}$ for $48 \mathrm{~h}$ compared to $24 \mathrm{~h}(p<0.05$, Figure $5 \mathrm{~B})$.

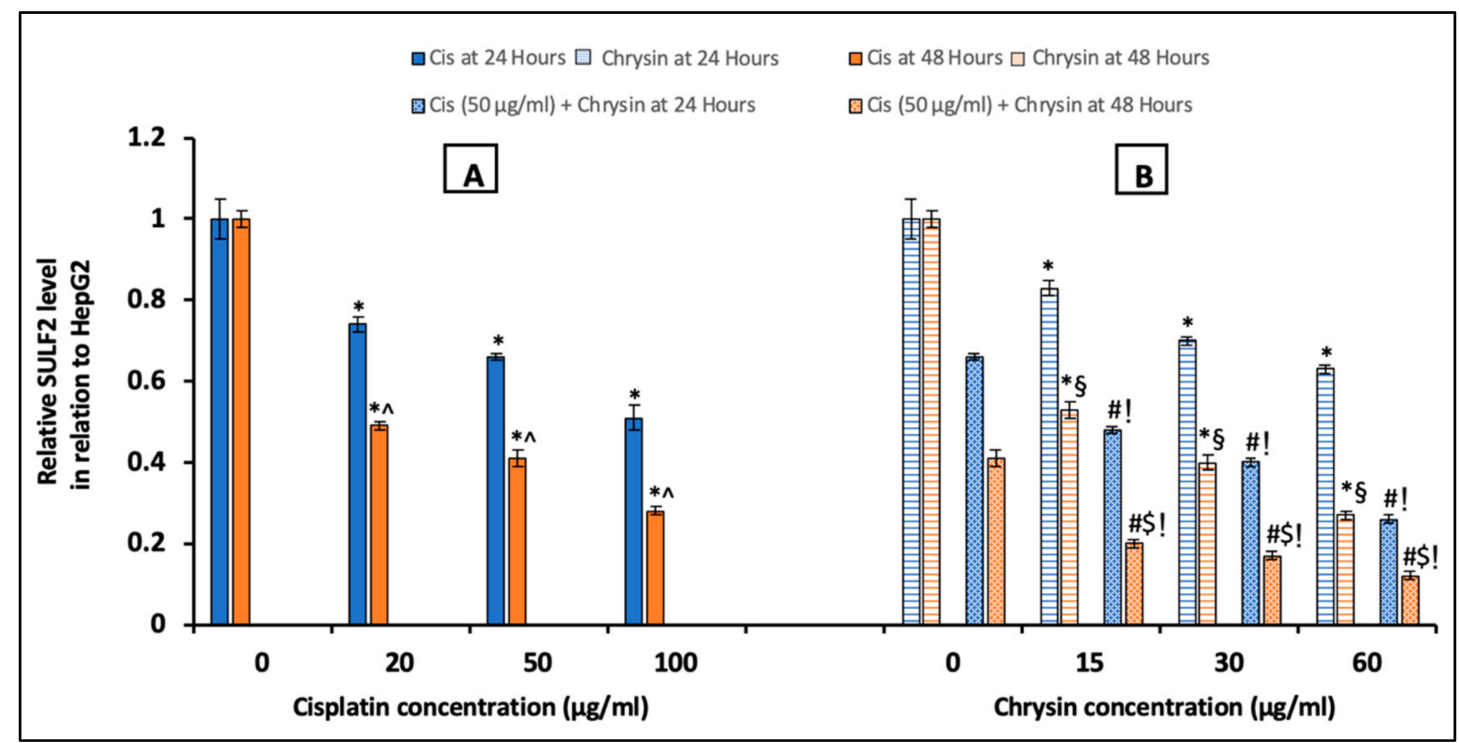

Figure 5. Impact of 24 and $48 \mathrm{~h}$ treatment with (A) cisplatin (Cis; 20, 50, $100 \mu \mathrm{g} / \mathrm{mL}$ ), (B) chrysin $(15,30,60 \mu \mathrm{g} / \mathrm{mL})$ and combination of chrysin $(15,30,60 \mu \mathrm{g} / \mathrm{mL})$ with Cis $50 \mu \mathrm{g} / \mathrm{mL}$ on sulfatase-2 (SULF2) protein levels in HepG2 cells. Results are presented as Mean \pm SD. ${ }^{*} p<0.05$ versus the control untreated cells. ${ }^{\wedge} p<0.05$ versus the same dose of Cis treatment for $24 \mathrm{~h} .{ }^{\#} p<0.05$ versus the same dose of chrysin at the same incubation time. ${ }^{!} p<0.05$ versus Cis $50 \mu \mathrm{g} / \mathrm{mL}$ at the same incubation time. $\S p<0.05$ versus the same dose of chrysin treatment for $24 \mathrm{~h} .{ }^{\$} p<0.05$ versus cis $50 \mu \mathrm{g} / \mathrm{mL}+$ the same dose of chrysin treatment for $24 \mathrm{~h}$. 
On the mRNA level, HepG2 cells incubated with cisplatin $(20,50,100 \mu \mathrm{g} / \mathrm{mL}$ ) (Figure 6A) or chrysin $(15,30,60 \mu \mathrm{g} / \mathrm{mL}$ ) (Figure $6 \mathrm{~B})$ for $48 \mathrm{~h}$ revealed a significant dose-dependent downregulation in SULF2 mRNA expression compared to the control untreated HepG2 cells. Moreover, co-treatment of chrysin $(15-60 \mu \mathrm{g} / \mathrm{mL})$ with $50 \mu \mathrm{g} / \mathrm{mL}$ cisplatin resulted in a more notable reduction in SULF2 mRNA expression in HepG2 cells compared to chrysin $(15-60 \mu \mathrm{g} / \mathrm{mL})$ single treatment or cisplatin $50 \mu \mathrm{g} / \mathrm{mL}$, $(p<0.05$, Figure 6B).

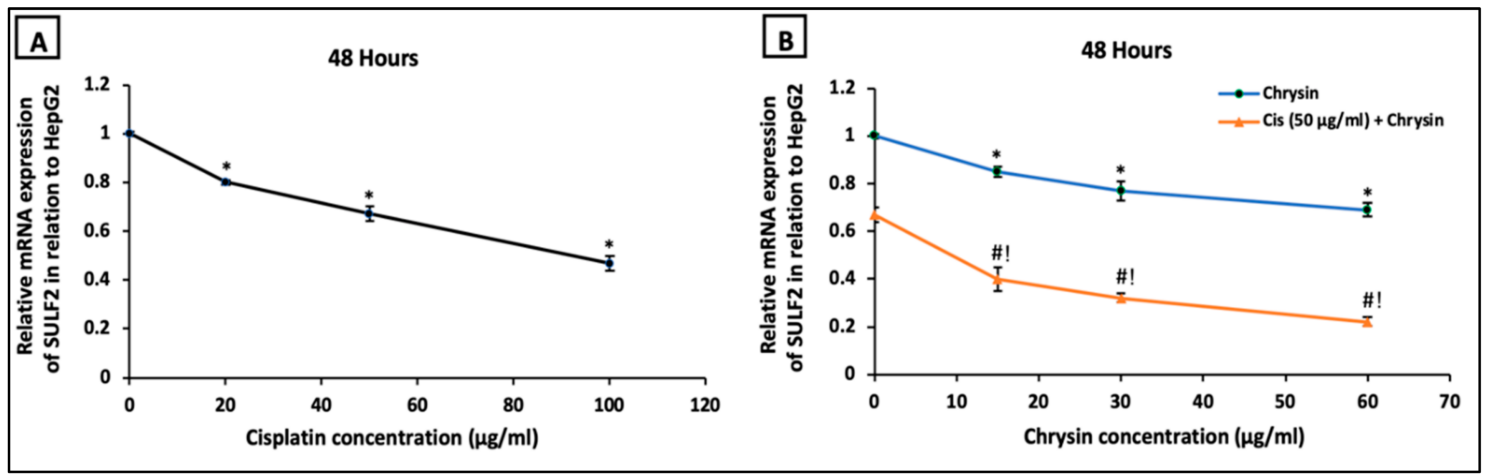

Figure 6. Impact of $48 \mathrm{~h}$ treatment with (A) cisplatin (Cis; 20, 50, $100 \mu \mathrm{g} / \mathrm{mL}),($ B) chrysin $(15,30$, $60 \mu \mathrm{g} / \mathrm{mL}$ ) and combination of chrysin $(15,30,60 \mu \mathrm{g} / \mathrm{mL}$ ) with Cis $50 \mu \mathrm{g} / \mathrm{mL}$ on sulfatase-2 (SULF2) mRNA expressions of in HepG2 cells. Results are presented as Mean \pm SD. ${ }^{*} p<0.05$ versus the control untreated cells. ${ }^{\#} p<0.05$ versus the same dose of chrysin. ${ }^{!} p<0.05$ versus Cis $50 \mu \mathrm{g} / \mathrm{mL}$.

\subsection{Chrysin Combined with Cisplatin Decreased lncRNA-AF085935 Expression in HepG2 Cells}

Next, we examined if the antiproliferative action of chrysin and cisplatin on HepG2 cells involved the lncRNA-AF085935. As shown in Figure 7, HepG2 cells were treated with increasing concentrations of cisplatin $(20,50,100 \mu \mathrm{g} / \mathrm{mL})(A)$ or chrysin $(15,30,60 \mu \mathrm{g} / \mathrm{mL})$ (B) for $48 \mathrm{~h}$. Except for chrysin $15 \mu \mathrm{g} / \mathrm{mL}$, chrysin or cisplatin single treatment significantly reduced the lncRNA-AF085935 expression in a dose-dependent manner compared with the control untreated HepG2 cells. Furthermore, lncRNA-AF085935 expression was significantly downregulated by both chrysin $(15-60 \mu \mathrm{g} / \mathrm{mL})$ and cisplatin $50 \mu \mathrm{g} / \mathrm{mL}$ as a combination treatment when compared with chrysin $(15-60 \mu \mathrm{g} / \mathrm{mL})$ alone or cisplatin $50 \mu \mathrm{g} / \mathrm{mL}(p<0.05$, Figure 7B).

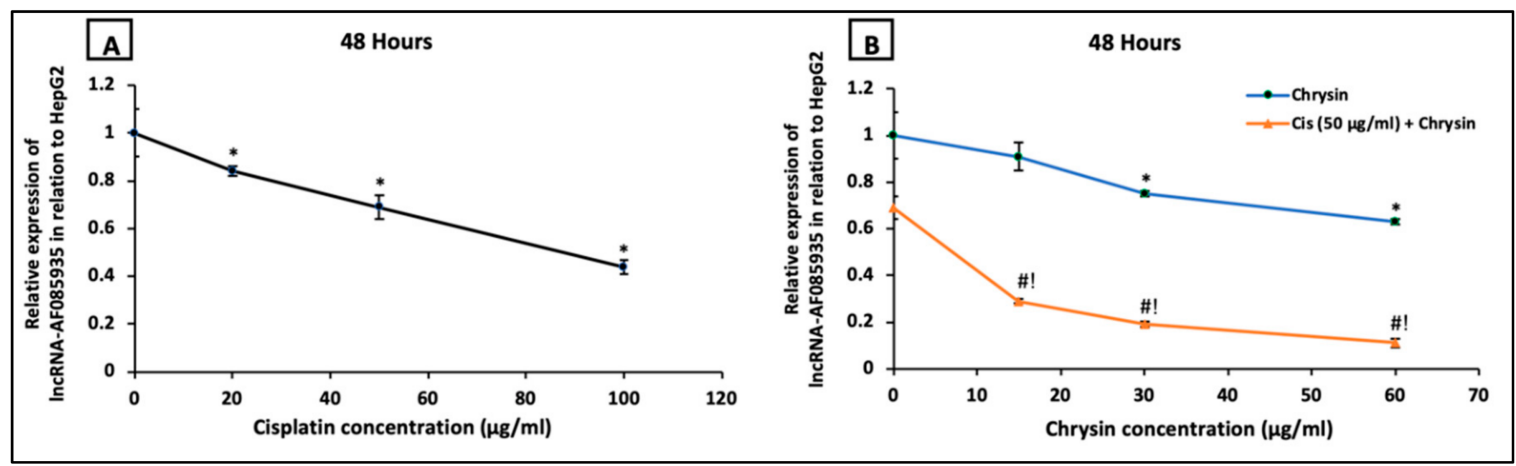

Figure 7. Impact of $48 \mathrm{~h}$ treatment with (A) cisplatin (Cis; 20, 50, $100 \mu \mathrm{g} / \mathrm{mL}),($ B) chrysin $(15,30$, $60 \mu \mathrm{g} / \mathrm{mL})$ and combination of chrysin $(15,30,60 \mu \mathrm{g} / \mathrm{mL})$ with Cis $50 \mu \mathrm{g} / \mathrm{mL}$ on 1 cRNA-AF085935 expression in HepG2 cells. Results are presented as Mean \pm SD. ${ }^{*} p<0.05$ versus the control untreated cells. ${ }^{\#} p<0.05$ versus the same dose of chrysin. ${ }^{!} p<0.05$ versus Cis $50 \mu \mathrm{g} / \mathrm{mL}$.

\section{Discussion}

The HCC is a common malignancy and its management with various chemotherapeutic agents is associated with severe toxicity [34]. Thus, to minimize their toxicity, natural products have been 
extensively used as anticancer drugs due to their safety. However, extensive investigations were applied to determine the underlying molecular mechanism of the antiproliferative action of these natural products [20].

As tumor cells are characterized by excessive proliferation, the inhibition of proliferation is considered as a good indicator for effective antitumor therapy [35]. According to our results of the MTT assay, which was used to examine the cell viability and proliferation, the present study reported doseand time-dependent antiproliferative activity of chrysin alone and/or in combination with cisplatin in HepG2 cells confirming that chrysin could potentiate the antitumor activity of cisplatin. In a similar way, previous reports documented the antiproliferative effect of chrysin against different human cancers, such as ovarian [36], gastric [37], and colorectal [17] cancers, in addition to hepatocellular carcinoma cells [20].

Moreover, it was found that GPC3, SULF2, and lncRNA-A F085935 were implicated in the proliferation of HCC with bad prognosis when overexpressed [25,33]. Therefore, our results provide a novel insight to clarify the anticancer capability of chrysin against HCC via GPC3/SULF2 axis and lncRNA-A F085935 expression. We evaluated the effect of chrysin and/or cisplatin on GPC3, a membrane-bound glycoprotein in which the protein core is covalently linked to HS GAG chains. GPC3 is known as a regulator of various growth factors and cellular pathways that modulate cellular proliferation, such as fibroblast growth factors, hedgehogs, and Wnt [38]. Wang and his colleagues, (2018), correlated GPC3 expression with liver cancer differentiation in HCC patients and reported that GPC3 promoted HepG2 cells proliferation through the hedgehog pathway [39]. Moreover, it was reported that GPC3 stimulated hepatocarcinogenesis in vitro and in vivo via stimulation of Wnt signaling [40].

Interestingly, GPC3 is overexpressed in HCC cells with rare expression in normal healthy cells and pathological liver cells [41]. The GPC3-immunohistochemistry has been proven as a prognostic tool for patients with HCC [26]. Capurro et al. (2005) demonstrated positive GPC3 immunolabeling in $72 \%$ of HCCs, highlighting GPC3 as a promising diagnostic marker and therapeutic target for HCC [42].

Indeed, many researchers proposed GPC 3 as the target of effective cytotoxic agents against HCC $[25,26,43]$. Epigallocatechin-3-gallate, a polyphenol of the natural product green tea, in addition to sodium ascorbate, a form of vitamin $C$, was recently reported to exert their antiproliferative action against HCC through a marked reduction in GPC3 protein expression [25,33]. Similarly, the results of this study revealed that chrysin alone and its combination with cisplatin markedly reduced cellular GPC3 protein, immunostaining, as well as mRNA expressions in HepG2 cells, compared to untreated HepG2 cells in a dose- and time-dependent manner, confirming the involvement of GPC 3 suppression as a novel antiproliferative mechanism for chrysin against HCC.

On the other hand, it has been found that the family of heparin-degrading endosulfatases involving SULF1 and SULF2 were implicated in the pathophysiology of numerous cancers, including HCC with an opposing action either as a tumor suppressor action with SULF1 or as an oncogenic action with SULF2. It was proposed that their effects on cancer development were mediated by desulfation of HSPGs. Lai et al. (2008) explained the role of SULF2 in enhancing cell growth of HCC by desulfation of growth factor ligands that are sequestered in HSPGs storage sites in a sulfation form. Upon desulfation by SULFs, factors are released and bound to their corresponding receptors resulting in cell growth [44]. Thus, the desulfation of GPC3 by SULF2 resulted in reduction of the affinity of GPC3 for its signaling ligands with subsequent release of these ligands from GPC3 storage sites making them accessible for stimulating different pathways [25].

Moreover, the SULF2 oncogenic role was suggested to be related to the activation of several pathways, including the receptor tyrosine kinase signaling and its downstream pathways of MAPK and Akt, in addition to Wnt pathway [45]. In this context, Lai et al. (2010) reported that GPC3-dependent Wnt activation mediated the oncogenic effect of SULF2 in HCC. Desulfation of GPC3 by SULF2 released Wnt from storage sites on GPC3 followed by Wnt/ $\beta$-catenin pathway activation [46]. 
Of note, SULF2 inhibitors showed chemotherapeutic benefits in HCC [25,30,47]. In agreement, treatment of HepG2 with chrysin and/or cisplatin in the present study significantly reduced SULF2 at protein and mRNA levels in dose- and time-dependent manner. Moreover, nearly similar results of GPC3 and SULF2 protein levels were observed when treating HepG2 cells with chrysin alone for $48 \mathrm{~h}$ or combination for $24 \mathrm{~h}$ confirming the chemopreventive potential of chrysin against HCC via GPC3/SULF2 axis.

Mounting evidences demonstrated involvement of lncRNAs in HCC onset, development, and metastasis. Indeed, dysregulation of various lncRNAs have been reported in HCC [48]. Among them, lncRNA-AF085935 has been strongly implicated. Motawi et al. (2019) reported elevated serum level of lncRNA-AF085935 in HCC patients, suggesting its use as a useful biomarker [49]. Interestingly, lncRNA-AF085935 is transcribed in antisense orientation with respect to GPC3. Moreover, lncRNA-AF085935 was upregulated and coexpressed with GPC3 in HCC cells and tissues [33,50].

Overexpression of lncRNA-AF085935 was accompanied by enhancement of HCC cell proliferation and metastasis. This effect was dependent on GPC3 upregulation. In contrast, lncRNA-AF085935 knockdown resulted in inhibition of HCC cell proliferation and migration, suggesting lncRNA-AF085935 as oncogene in HCC [51].

Based on the aforementioned studies, we examined if lncRNA-AF085935 is involved in the antiproliferative activity of chrysin and cisplatin on HepG2. Our results showed that chrysin and/or cisplatin markedly reduced lncRNA-AF085935 expression in HepG2 cells in a dose-dependent manner highlighting the novel role acted by chrysin in lncRNA-AF085935 regulation. This finding was consistent with a previous study that reported the antiproliferative and antiapoptotic action of epigallocatechin-3-gallate was associated with lncRNA-AF085935 suppression in HCC [33].

Galijatovic et al. demonstrated that chrysin is metabolized by conjugation pathways, including both glucuronidation and sulfation in both intestinal and hepatic cells [52]. Despite the beneficial bioactive effects of chrysin, its clinical application is limited owing to poor bioavailability as well as rapid metabolism and excretion. Therefore, current studies are attempting to enhance its pharmacokinetic properties via nano-modification. Of note, various in vitro studies reported anti-proliferative effect of chrysin in a time-dependent manner $[53,54]$. Inline, our data showed a time-dependent anti-proliferative effect of chrysin either alone or in combination with cisplatin.

In conclusion, this study is the first report to reveal that chrysin antiproliferative action against HCC could be attributed to the suppression of GPC3/SULF2 protein and mRNA expressions along with the downregulation of lncRNA-AF085935 expression. The combination of chrysin with cisplatin produced more favorable results in a dose- and time-dependent manner, suggesting that the use of chrysin as an adjuvant therapy could reduce the required dose of cisplatin and, hence, ameliorate its side effects. Further studies are required to delineate the downstream signaling ligands of GPC3 that could be targeted by chrysin in HCC.

\section{Materials and methods}

\subsection{Drugs}

Chrysin was provided as a 5 gm faint yellow powder from Sichuan Benepure Pharmaceutical Co., Ltd., Chengdu, China, while cisplatin was obtained as a $50 \mathrm{~mL}$ vial $(1 \mathrm{mg} / \mathrm{mL})$ from Hospira, Warwickshire, UK.

\subsection{Cell Culture}

The human hepatocellular carcinoma (HepG2) cell line was provided from the American Type Culture Collection (ATCC, Minnesota, USA) and grown using Roswell Park Memorial Institute (RPMI) 1640 culture media (Lonza Bioscience, Alpharetta, GA, USA), adding 10\% fetal bovine serum, $2 \mathrm{mM}$ glutamine, in addition to antibiotics of $1 \%$ penicillin/ streptomycin at $37^{\circ} \mathrm{C}$ in a $\mathrm{CO}_{2}$ incubator. Table 1 
illustrates the cell treatment protocol in which the concentrations of cisplatin and chrysin used for this study were similar to those reported before in previous studies $[7,12,20,55]$.

Table 1. Treatment protocol of HepG2 cells with different concentrations of cisplatin and chrysin at different time interval.

\begin{tabular}{|c|c|}
\hline Group & Culture Description \\
\hline Control & Untreated HepG2 cells cultured for 24 and $48 \mathrm{~h}$. \\
\hline Cisplatin & $\begin{array}{l}\text { HepG2 cells treated with three concentrations of cisplatin (Cis; 20, 50, and } \\
\qquad 100 \mu \mathrm{g} / \mathrm{mL} \text { ) for } 24 \text { and } 48 \mathrm{~h} \text {. }\end{array}$ \\
\hline Chrysin & $\begin{array}{l}\text { HepG2 cells treated with three concentrations of chrysin }(15,30 \text {, and } \\
\qquad 60 \mu \mathrm{g} / \mathrm{mL}) \text { for } 24 \text { and } 48 \mathrm{~h} \text {. }\end{array}$ \\
\hline Combination & $\begin{array}{l}\text { HepG2 cells treated with combined Cis } 50 \mu \mathrm{g} / \mathrm{mL} \text { and three concentrations of } \\
\text { chrysin }(15,30 \text {, and } 60 \mu \mathrm{g} / \mathrm{mL}) \text { for } 24 \text { and } 48 \mathrm{~h} \text {. }\end{array}$ \\
\hline
\end{tabular}

\subsection{MTT Assay for Cell Viability}

The MTT cell proliferation assay $\left(\mathrm{TACS}^{\mathrm{TM}}\right.$ MTT, Trevigen ${ }^{\circledR}$, Hagerman CT, Gaithersburg) was used for assessing cell viability according to the manufacturer's instructions. HepG2 cells $\left(1 \times 10^{3}\right)$ were placed in 96 well microplate $24 \mathrm{~h}$ before MTT assay. A $50 \mu \mathrm{L}$ of serum-free media was added to cells and $10 \mu \mathrm{L}$ of MTT solution into each well. The plate was incubated at $37^{\circ} \mathrm{C}$ for $3 \mathrm{~h}$. After incubation, $100 \mu \mathrm{L}$ of detergent solution (MTT formazan) was added into each well, and then the plate was covered and incubated overnight at $37^{\circ} \mathrm{C}$. An ELISA plate reader was used to measure the color absorbance at optical density (O.D.) $590 \mathrm{~nm}$, duplicate readings were taken, and then averaged for each sample. The amount of absorbance was proportional to cell number.

\subsection{Immunocytochemistry (ICC) for the Detection of GPC3 Protein Expression}

Immunocytochemistry technique was used to detect the immunopositive cells for GPC 3 in the HepG2 liver cancer cell line. The cells were seeded on a 96 well plate with glass bottom followed by fixation of the cells in 100\% methanol/10min at room temperature in addition to permeabilization with $0.25-0.5 \%$ Triton X-100 in PBS/10 min. After that, incubation for $24 \mathrm{~h}$ with GPC3 primary antibody (1:500, Abcam, Cambridge, UK) was performed. Washing after the immunostaining step was applied and secondary antibody anti-rabbit IgG (1:1000) was added for $1 \mathrm{~h}$. Finally, the percentage number of GPC3 immuno-expression cells was quantified in five images/each group using the Image-Pro Plus program.

\subsection{Enzyme-Linked Immunosorbent Assay (ELISA) for the Determination of GPC3/SULF2 Protein Levels}

Cells at $1 \times 10^{7}$ cells $/ \mathrm{mL}$ were suspended and lysed in cell lysis buffer, and then incubation with gentle agitation was done at room temperature for up to $1 \mathrm{~h}$. In cell lysate, total protein concentration was measured by the Bradford method using the Bradford protein assay kit provided by Bio Basic Inc., Ontario, Canada, according to manual instructions. The GPC3 and SULF2 protein concentration levels were assessed in cell lysate as pg/mg cell protein by using human GPC3/SULF2 ELISA kits provided from Creative Diagnostics, Shirly, NY, USA and Abbkine Scientific Co., Ltd., Wuhan, China, respectively, according to manual instructions.

4.6. Quantitative Real-Time Polymerase Chain Reaction ( $q P C R$ ) for the Estimation of GPC3/SULF2 mRNA Expression and lncRNA-AF085935 Expression

From cells of all groups, the total RNA was extracted with Direct-zol ${ }^{\mathrm{TM}}$ RNA Miniprep Plus kits (Zymo Research Corp., CA, USA), then its quantity and quality were examined by Beckman dual spectrophotometer. The SuperScript IV One-Step RT-PCR kit (Thermo Fisher Scientific, Waltham, MA, USA) was utilized for reverse transcription of extracted RNA followed by PCR. A 48-well plate StepOne 
instrument (Applied Biosystems, USA) was used in a thermal profile as follows: 10 min at $45^{\circ} \mathrm{C}$ for reverse transcription, $2 \mathrm{~min}$ at $98^{\circ} \mathrm{C}$ for RT inactivation, initial denaturation by 40 cycles of $10 \mathrm{~s} \mathrm{at} 98^{\circ} \mathrm{C}$, $10 \mathrm{~s}$ at $55^{\circ} \mathrm{C}$, and $30 \mathrm{~s}$ at $72{ }^{\circ} \mathrm{C}$ for the amplification step. After the RT-PCR run, the data were expressed in cycle threshold $(\mathrm{Ct})$ for the studied genes and $\beta$-actin as a housekeeping gene. Normalization for variation in the expression of each target gene; GPC 3, SULF2, and lncRNA-AF085935 was carried out referring to the mean critical threshold (CT) expression values of $\beta$-actin by the $\Delta \Delta \mathrm{Ct}$ method. The relative quantitation of each gene is quantified according to the calculation of the $2^{-\Delta \Delta \mathrm{Ct}}$ method. Primers sequence used for target genes was presented in Table 2.

Table 2. Primers sequence of the studied genes.

\begin{tabular}{ccc}
\hline Genes & Forward $\left(\mathbf{5}^{\prime}-\mathbf{3}^{\prime}\right)$ & Reverse $\left(5^{\prime}-\mathbf{3}^{\prime}\right)$ \\
\hline$\beta$-actin & ATGCTCTCCCTCACGCCATC & CAGGATTCCATACCCAAGA \\
\hline GPC3 & GTCCCTGAACGCGACTATTT & AGCTTGTGCCAGCTCTTT \\
\hline SULF2 & CTGAATCCCCACATCGTCCTC & GTCCACCTTGTCATTGTCTCTCTTGT \\
\hline lncRNA AF085935 & CAGGGCAGCAAGGTGTTTTC & TTGGTGGGT TGCCTGATACC \\
\hline
\end{tabular}

\subsection{Data Analysis}

The IBM SPSS software version 20 was utilized for performing the statistical analysis of this study. The results were presented as mean \pm standard deviation. To evaluate the differences between groups, the one-way analysis of variance (ANOVA) accompanied by post-hoc Bonferroni correction test was applied. A p value of less than 0.05 was considered statistically significant.

Author Contributions: Conceptualization, I.O.S.; formal analysis, I.O.S., L.A.A.-M., N.M.E.; funding acquisition, L.A.A.-M.; investigation I.O.S., D.S., N.M.E.; supervision, L.A.A.-M.; writing-original draft, I.O.S., D.S., N.M.E.; writing-review and editing, I.O.S., L.A.A.-M., D.S., N.M.E. All authors have read and agreed to the published version of the manuscript.

Funding: This research was funded by the Deanship of Scientific Research at Princess Nourah bint Abdulrahman University through the Fast-Track Research Funding Program.

Conflicts of Interest: The authors declare no competing interests.

\section{References}

1. Zhu, R.X.; Seto, W.-K.; Lai, C.-L.; Yuen, M.-F. Epidemiology of hepatocellular carcinoma in the Asia-Pacific region. Gut Liver 2016, 10, 332. [CrossRef]

2. Li, H.; Jiang, D.; Zhang, L.; Wu, J. Inhibition of tumor growth of human hepatocellular carcinoma HepG2 cells in a nude mouse xenograft model by the total flavonoids from Arachniodes exilis. Evid. Based Complement. Altern. Med. 2017. [CrossRef]

3. Wu, Y.; Liu, H.; Ding, H. GPC-3 in hepatocellular carcinoma: Current perspectives. J. Hepatocell. Carcinoma 2016, 3, 63. [CrossRef] [PubMed]

4. Zhong, C.; Qiu, S.; Li, J.; Shen, J.; Zu, Y.; Shi, J.; Sui, G. Ellagic acid synergistically potentiates inhibitory activities of chemotherapeutic agents to human hepatocellular carcinoma. Phytomedicine 2019, 59, 152921. [CrossRef] [PubMed]

5. Tayel, A.; El Galil, K.H.A.; Ebrahim, M.A.; Ibrahim, A.S.; El-Gayar, A.M.; Al-Gayyar, M.M. Suramin inhibits hepatic tissue damage in hepatocellular carcinoma through deactivation of heparanase enzyme. Eur. J. Pharmacol. 2014, 728, 151-160. [CrossRef] [PubMed]

6. Roy, G.; Guan, S.; Liu, H.; Zhang, L. Rotundic acid induces DNA damage and cell death in hepatocellular carcinoma through AKT/mTOR and MAPK pathways. Front. Oncol. 2019, 9, 545. [CrossRef]

7. Sherif, I.O.; Al-Gayyar, M.M. Oleuropein potentiates anti-tumor activity of cisplatin against HepG2 through affecting proNGF/NGF balance. Life Sci. 2018, 198, 87-93. [CrossRef] 
8. Zhang, L.; Jiang, G.; Yao, F.; He, Y.; Liang, G.; Zhang, Y.; Hu, B.; Wu, Y.; Li, Y.; Liu, H. Growth inhibition and apoptosis induced by osthole, a natural coumarin, in hepatocellular carcinoma. PLoS ONE 2012, 7, e37865. [CrossRef]

9. Liu, Z.; Peng, Q.; Li, Y.; Gao, Y. Resveratrol enhances cisplatin-induced apoptosis in human hepatoma cells via glutamine metabolism inhibition. BMB Rep. 2018, 51, 474. [CrossRef]

10. Wu, Z.; Wu, J.; Fang, P.; Kan, S. Puerarin increases the chemosensitivity of hepatocellular carcinoma cells. Oncol. Lett. 2017, 14, 3006-3010. [CrossRef]

11. Li, M.; Chen, J.; Yu, X.; Xu, S.; Li, D.; Zheng, Q.; Yin, Y. Myricetin suppresses the propagation of hepatocellular carcinoma via down-regulating expression of YAP. Cells 2019, 8, 358. [CrossRef] [PubMed]

12. Xu, D.; Jin, J.; Yu, H.; Zhao, Z.; Ma, D.; Zhang, C.; Jiang, H. Chrysin inhibited tumor glycolysis and induced apoptosis in hepatocellular carcinoma by targeting hexokinase-2. J. Exp. Clin. Cancer Res. 2017, 36, 44. [CrossRef] [PubMed]

13. Oliveira, G.; Ferraz, E.; Souza, A.; Lourenco, R.; Oliveira, D.P.; Dorta, D.J. Evaluation of the mutagenic activity of chrysin, a flavonoid inhibitor of the aromatization process. J. Toxicol. Environ. Health Part A 2012, 75, 1000-1011. [CrossRef] [PubMed]

14. Gao, A.-M.; Ke, Z.-P.; Shi, F.; Sun, G.-C.; Chen, H. Chrysin enhances sensitivity of BEL-7402/ADM cells to doxorubicin by suppressing PI3K/Akt/Nrf2 and ERK/Nrf2 pathway. Chem. Biol. Interact. 2013, 206, 100-108. [CrossRef]

15. Mohammadian, F.; Pilehvar-Soltanahmadi, Y.; Alipour, S.; Dadashpour, M.; Zarghami, N. Chrysin alters microRNAs expression levels in gastric cancer cells: Possible molecular mechanism. Drug Res. 2017, 67, 509-514. [CrossRef]

16. Samarghandian, S.; Azimi-Nezhad, M.; Borji, A.; Hasanzadeh, M.; Jabbari, F.; Farkhondeh, T.; Samini, M. Inhibitory and cytotoxic activities of chrysin on human breast adenocarcinoma cells by induction of apoptosis. Pharmacogn. Mag. 2016, 12 (Suppl. S4), S436.

17. Lin, Y.-M.; Chen, C.-I.; Hsiang, Y.-P.; Hsu, Y.-C.; Cheng, K.-C.; Chien, P.-H.; Pan, H.-L.; Lu, C.-C.; Chen, Y.-J. Chrysin attenuates cell viability of human colorectal cancer cells through autophagy induction unlike 5-fluorouracil/oxaliplatin. Int. J. Mol. Sci. 2018, 19, 1763. [CrossRef]

18. Ryu, S.; Lim, W.; Bazer, F.W.; Song, G. Chrysin induces death of prostate cancer cells by inducing ROS and ER stress. J. Cell. Physiol. 2017, 232, 3786-3797. [CrossRef] [PubMed]

19. Kasala, E.R.; Bodduluru, L.N.; Madana, R.M.; Gogoi, R.; Barua, C.C. Chemopreventive and therapeutic potential of chrysin in cancer: Mechanistic perspectives. Toxicol. Lett. 2015, 233, 214-225. [CrossRef]

20. Zhang, Q.; Ma, S.; Liu, B.; Liu, J.; Zhu, R.; Li, M. Chrysin induces cell apoptosis via activation of the p53/Bcl-2/caspase-9 pathway in hepatocellular carcinoma cells. Exp. Ther. Med. 2016, 12, 469-474. [CrossRef] [PubMed]

21. Rehman, M.U.; Ali, N.; Rashid, S.; Jain, T.; Nafees, S.; Tahir, M.; Khan, A.Q.; Lateef, A.; Khan, R.; Hamiza, O.O. Alleviation of hepatic injury by chrysin in cisplatin administered rats: Probable role of oxidative and inflammatory markers. Pharmacol. Rep. 2014, 66, 1050-1059. [CrossRef] [PubMed]

22. Khan, R.; Khan, A.Q.; Qamar, W.; Lateef, A.; Tahir, M.; Rehman, M.U.; Ali, F.; Sultana, S. Chrysin protects against cisplatin-induced colon. toxicity via amelioration of oxidative stress and apoptosis: Probable role of p38MAPK and p53. Toxicol. Appl. Pharmacol. 2012, 258, 315-329. [CrossRef]

23. Wu, X.Z.; Chen, D.; Xie, G.R. Extracellular matrix remodeling in hepatocellular carcinoma: Effects of soil on seed? Med Hypotheses 2006, 66, 1115-1120. [CrossRef] [PubMed]

24. Lin, X. Functions of heparan sulfate proteoglycans in cell signaling during development. Development 2004, 131, 6009-6021. [CrossRef] [PubMed]

25. Alyoussef, A.; Al-Gayyar, M.M. Cytotoxic and partial hepatoprotective activity of sodium ascorbate against hepatocellular carcinoma through inhibition of sulfatase-2 in vivo and in vitro. Biomed. Pharmacother. 2018, 103, 362-372. [CrossRef]

26. Nishida, T.; Kataoka, H. Glypican 3-Targeted Therapy in Hepatocellular Carcinoma. Cancers 2019, 11, 1339. [CrossRef]

27. Qiao, S.-S.; Cui, Z.; Gong, L.; Han, H.; Chen, P.-C.; Guo, L.-M.; Yu, X.; Wei, Y.-H.; Ha, S.-A.; Kim, J.W. Simultaneous measurements of serum AFP, GPC-3 and HCCR for diagnosing hepatocellular carcinoma. Hepato Gastroenterol. 2011, 58, 1718-1724. [CrossRef] 
28. Carr, R.M.; Duran, P.A.R.; Tolosa, E.J.; Ma, C.; Oseini, A.M.; Moser, C.D.; Banini, B.A.; Huang, J.; Asumda, F.; Dhanasekaran, R. The extracellular sulfatase SULF2 promotes liver tumorigenesis by stimulating assembly of a promoter-looping GLI1-STAT3 transcriptional complex. J. Biol. Chem. 2020, 295, 2698-2712. [CrossRef]

29. Zaghloul, R.A.; El-Shishtawy, M.M.; El Galil, K.H.A.; Ebrahim, M.A.; Metwaly, A.A.; Al-Gayyar, M.M. Evaluation of antiglypican-3 therapy as a promising target for amelioration of hepatic tissue damage in hepatocellular carcinoma. Eur. J. Pharmacol. 2015, 746, 353-362. [CrossRef]

30. Zheng, X.; Gai, X.; Han, S.; Moser, C.D.; Hu, C.; Shire, A.M.; Floyd, R.A.; Roberts, L.R. The human sulfatase 2 inhibitor 2, 4-disulfonylphenyl-tert-butylnitrone (OKN-007) has an antitumor effect in hepatocellular carcinoma mediated via suppression of TGFB1/SMAD2 and Hedgehog/GLI1 signaling. Genes Chromosom. Cancer 2013, 52, 225-236. [CrossRef]

31. Bolha, L.; Ravnik-Glavač, M.; Glavač, D. Long noncoding RNAs as biomarkers in cancer. Dis. Markers 2017, 2017. [CrossRef]

32. Bao, H.; Su, H. Long noncoding RNAs act as novel biomarkers for hepatocellular carcinoma: Progress and prospects. Biomed Res. Int. 2017, 2017. [CrossRef]

33. Sabry, D.; Abdelaleem, O.O.; Ali, A.M.; Mohammed, R.A.; Abdel-Hameed, N.D.; Hassouna, A.; Khalifa, W.A. Anti-proliferative and anti-apoptotic potential effects of epigallocatechin-3-gallate and/or metformin on hepatocellular carcinoma cells: In vitro study. Mol. Biol. Rep. 2019, 46, 2039-2047. [CrossRef]

34. Au, J.S.; Frenette, C.T. Management of hepatocellular carcinoma: Current status and future directions. Gut Liver 2015, 9, 437. [CrossRef]

35. Hanahan, D.; Weinberg, R.A. Hallmarks of cancer: The next generation. Cell 2011, 144, 646-674. [CrossRef]

36. Lim, W.; Ryu, S.; Bazer, F.W.; Kim, S.M.; Song, G. Chrysin attenuates progression of ovarian cancer cells by regulating signaling cascades and mitochondrial dysfunction. J. Cell. Physiol. 2018, 233, 3129-3140. [CrossRef]

37. Zhong, X.; Liu, D.; Jiang, Z.; Li, C.; Chen, L.; Xia, Y.; Liu, D.; Yao, Q.; Wang, D. Chrysin Induced Cell Apoptosis and Inhibited Invasion Through Regulation of TET1 Expression in Gastric Cancer Cells. Oncotargets Ther. 2020, 13, 3277. [CrossRef]

38. Kolluri, A.; Ho, M. The role of glypican-3 in regulating Wnt, YAP and hedgehog in liver cancer. Front. Oncol. 2019, 9, 708. [CrossRef]

39. Wang, S.; Chen, N.; Chen, Y.; Sun, L.; Li, L.; Liu, H. Elevated GPC3 level promotes cell proliferation in liver cancer. Oncol. Lett. 2018, 16, 970-976. [CrossRef]

40. Gao, W.; Ho, M. The role of glypican-3 in regulating Wnt in hepatocellular carcinomas. Cancer Rep. 2011, 1, 14.

41. Guo, M.; Zhang, H.; Zheng, J.; Liu, Y. Glypican-3: A New Target for Diagnosis and Treatment of Hepatocellular Carcinoma. J. Cancer 2020, 11, 2008. [CrossRef]

42. Capurro, M.I.; Xiang, Y.-Y.; Lobe, C.; Filmus, J. Glypican-3 promotes the growth of hepatocellular carcinoma by stimulating canonical Wnt signaling. Cancer Res. 2005, 65, 6245-6254. [CrossRef]

43. Gong, T.; Ning, X.; Deng, Z.; Liu, M.; Zhou, B.; Chen, X.; Huang, S.; Xu, Y.; Chen, Z.; Luo, R. Propofol-induced miR-219-5p inhibits growth and invasion of hepatocellular carcinoma through suppression of GPC3-mediated Wnt/ß-catenin signalling activation. J. Cell. Biochem. 2019, 120, 16934-16945. [CrossRef]

44. Lai, J.P.; Sandhu, D.S.; Yu, C.; Han, T.; Moser, C.D.; Jackson, K.K.; Guerrero, R.B.; Aderca, I.; Isomoto, H.; Garrity-Park, M.M. Sulfatase 2 up-regulates glypican 3, promotes fibroblast growth factor signaling, and decreases survival in hepatocellular carcinoma. Hepatology 2008, 47, 1211-1222. [CrossRef]

45. Yang, J.D.; Sun, Z.; Hu, C.; Lai, J.; Dove, R.; Nakamura, I.; Lee, J.S.; Thorgeirsson, S.S.; Kang, K.J.; Chu, I.S. Sulfatase 1 and sulfatase 2 in hepatocellular carcinoma: Associated signaling pathways, tumor phenotypes, and survival. Genes Chromosomes Cancer 2011, 50, 122-135. [CrossRef]

46. Lai, J.P.; Oseini, A.M.; Moser, C.D.; Yu, C.; Elsawa, S.F.; Hu, C.; Nakamura, I.; Han, T.; Aderca, I.; Isomoto, H. The oncogenic effect of sulfatase 2 in human hepatocellular carcinoma is mediated in part by glypican 3-dependent Wnt activation. Hepatology 2010, 52, 1680-1689. [CrossRef]

47. Al-Gayyar, M.M.; Abbas, A.; Hamdan, A.M. Chemopreventive and hepatoprotective roles of adiponectin (SULF2 inhibitor) in hepatocelluar carcinoma. Biol. Chem. 2016, 397, 257-267. [CrossRef]

48. Lu, J.; Xie, F.; Geng, L.; Shen, W.; Sui, C.; Yang, J. Investigation of serum lncRNA-uc003wbd and lncRNA-AF085935 expression profile in patients with hepatocellular carcinoma and HBV. Tumor Biol. 2015, 36, 3231-3236. [CrossRef] 
49. Motawi, T.M.; El-Maraghy, S.A.; Sabry, D.; Mehana, N.A. The expression of long non coding RNA genes is associated with expression with polymorphisms of HULC rs7763881 and MALAT1 rs619586 in hepatocellular carcinoma and HBV Egyptian patients. J. Cell. Biochem. 2019, 120, 14645-14656. [CrossRef]

50. Yuan, S.-X.; Tao, Q.-F.; Wang, J.; Yang, F.; Liu, L.; Wang, L.-L.; Zhang, J.; Yang, Y.; Liu, H.; Wang, F. Antisense long non-coding RNA PCNA-AS1 promotes tumor growth by regulating proliferating cell nuclear antigen in hepatocellular carcinoma. Cancer Lett. 2014, 349, 87-94. [CrossRef]

51. Zhu, X.T.; Yuan, J.H.; Zhu, T.T.; Li, Y.Y.; Cheng, X.Y. Long noncoding RNA glypican 3 (GPC3) antisense transcript 1 promotes hepatocellular carcinoma progression via epigenetically activating GPC3. FEBS J. 2016, 283, 3739-3754. [CrossRef]

52. Galijatovic, A.; Otake, Y.; Walle, U.; Walle, T. Extensive metabolism of the flavonoid chrysin by human Caco-2 and Hep G2 cells. Xenobiotica 1999, 29, 1241-1256. [CrossRef]

53. Chen, H.Y.; Jiang, Y.W.; Kuo, C.L.; Way, T.D.; Chou, Y.C.; Chang, Y.S.; Chung, J.G. Chrysin inhibit human melanoma A375. S2 cell migration and invasion via affecting MAPK signaling and NF- $\mathrm{B}$ signaling pathway in vitro. Environ. Toxicol. 2019, 34, 434-442. [CrossRef] [PubMed]

54. Mohammadian, F.; Abhari, A.; Dariushnejad, H.; Zarghami, F.; Nikanfar, A.; Pilehvar-Soltanahmadi, Y.; Zarghami, N. Upregulation of Mir-34a in AGS gastric cancer cells by a PLGA-PEG-PLGA chrysin nano formulation. Asian Pac. J. Cancer Prev. 2016, 16, 8259-8263. [CrossRef] [PubMed]

55. Ghavami, G.; Sardari, S. Synergistic Effect of Vitamin C with Cisplatin for Inhibiting Proliferation of Gastric Cancer Cells. Iran. Biomed. J. 2020, 24, 119-127. [CrossRef] [PubMed]

Publisher's Note: MDPI stays neutral with regard to jurisdictional claims in published maps and institutional affiliations.

(C) 2020 by the authors. Licensee MDPI, Basel, Switzerland. This article is an open access article distributed under the terms and conditions of the Creative Commons Attribution (CC BY) license (http://creativecommons.org/licenses/by/4.0/). 